http://visnyk.vntu.edu.ua/article/view/608/1847

7. Ландшеер В.

Концепция

«минимальной компетентности»/ В. Ландшеер // Перспективы. Вопросы образования. - 1988. - № 1/5. - С. 44-48. 8. Поваренков Ю. П. Психологическое содержание профессионального становления человека / Ю. П. Поваренков. - М.: Изд-во УРАО, 2002. - 212 с. 9. Професійна освіта: словник: навч. посіб. / [уклад. С. У. Гончаренко та ін.]; за ред. Н. Г. Ничкало. - К. : Вища школа, 2000. - 380 с. 10. Степашкина Л. Ю. Развитие общих учебных умений и навыков как ключевой образовательной компетенции [Електронний ресурс] / Л. Ю. Степашкина // Интернет-журнал «Эйдос». - 2005. - Режим доступу: http://www.eidos.ru/journal/2005/0910-09.htm 11. Стрельников В. Ю. Розвиток професійної компетентності вчителів у закладах післядипломної освіти: дис... канд. пед. Наук / В. Ю. Стрельников. - Київ, 1995. - 223 с. 12. Хуторской А. В. Ключевые компетенции и образовательные стандарты [Электронный ресурс] / А. В. Хуторской. - Режим доступу: http://eidos.ru/journal/2002/0423.htm

\title{
УДОСКОНАЛЕННЯ ЛЕКСИЧНИХ УМІНЬ І НАВИЧОК СТУДЕНТІВ У ПРОЦЕСІ НАВЧАННЯ УКРАЇНСЬКОЇ МОВИ (ЗА ПРОФЕСІЙНИМ СПРЯМУВАННЯМ)
}

Пасічна О. В.Удосконалення лексичних умінь і навичок студентів у процесі навчання української мови (за професійним спрямуванням).

У статті обгрунтовується необхідність застосування системи тренувальних вправ задля вдосконалення лексичних умінь i навичок студентів у сфері професійного спілкування. Запропонована система роботи дозволяє розширити словниковий запас студентів та попередити виникнення лексичних помилок.

Ключові слова: професійна комунікація, лексична компетенція, лексична помилка, тренувальні вправи, синоніми, пароніми, омоніми.

Пасечная Е. В. Усовершенствование лексических учений и навыков студентов в процессе обучения украинскому языку (по профессиональному направлению).

В статье обосновывается необходимость применения системы тренировочных упражнений для усовершенствования лексических умений и навыков студентов в сфере профессионального общения. Предложенная система работы позволяет расширить словарный запас студентов и предупредить появление лексических ошибок.

Ключевые слова: профессиональная коммуникация, лексическая компетенция, лексическая ошибка, тренировочные упражнения, синонимы, паронимы, омонимы.

Pasichna O. V. Improvement of the lexical skills of students in learning the Ukrainian language (for professional purposes).

In the paper the necessity of application of the system of training exercises to improve vocabulary skills of students in the field of professional communication is considered. The proposed system allows students to expand vocabulary and prevent the occurrence of lexical errors.

Key words: professional communication, lexical competence, lexical error, training exercises, synonyms, paronyms, homonyms. 
Сучасний стан вищої освіти в Україні характеризується посиленою увагою як до набуття студентами фахових знань, так $\mathrm{i}$ до формування їхньої мовнокомунікативної компетенції. У програмі курсу «Українська мова (за професійним спрямуванням)», укладеною С. Шевчук та І. Клименко, указується, що завдання вищої школи - готувати фахівців нової генерації: кваліфікованих, грамотних, мовно компетентних, які б досконало, грунтовно володіли українською літературною мовою в повсякденно-професійній, офіційно-документальній сфері, зокрема набули навичок комунікативно виправданого використання засобів мови, оволоділи мовою конкретної спеціальності, фаху. Укладачі цієї програми наголошують на тому, що акцент мовної освіти у ВНЗ переноситься 3 традиційної настанови - засвоєння відомостей про літературні норми всіх рівнів мовної ієрархії - на формування навичок професійної комунікації, студіювання особливостей фахової мови, на розвиток культури мови, мислення й поведінки особистості [3, с. 646].

Мовна компетенція фахівця складається 3 низки компетенцій, зокрема таких: орфоепічної, лексичної, граматичної, орфографічної, пунктуаційної. 3-поміж названих складників у формуванні професійних умінь і навичок саме лексична компетенція набуває першорядного значення, оскільки мова професії насамперед виявляється на лексичному рівні.

Mema cmammi- описати систему тренувальних вправ, які сприятимуть удосконаленню умінь і навичок студентів уживати синоніми, омоніми, пароніми у сфері професійного спілкування.

У курсі «Українська мова (за професійним спрямуванням)» робота 3 удосконалення лексичних умінь і навичок грунтується на засвоєних студентами ще в середній школі базових теоретичних поняттях: пряме та переносне значення слова; омоніми, синоніми, антоніми; лексика української мови за походженням; загальновживані слова та професійна, діалектна, розмовна лексика; лексика 3 погляду активного й пасивного вживання, стійкі сполуки слів тощо. Зазначимо, що текстовий матеріал для лексичної роботи добирається 3 певних комунікативних сфер, оскільки вивчення особливостей фахової мови передовсім пов'язане 3 функціонуванням слів у науковому, офіційно-діловому та розмовному стилях. Професійна сфера, як стверджують дослідники, репрезентує офіційно-діловий i науковий стилі у єдності спільних мовних засобів досягнення комунікативної мети, адже кожна людина, незалежно від фаху, віку, статі, соціального становища, стикається 3 проблемою написання заяви, службової довідки, листа, виступу. Крім того, основою професійної підготовки є комунікативна компетенція, тобто вміння й навички говорити, запитувати, відповідати, аргументувати, переконувати, висловлювати точно і ясно думку, правильно поводити себе в конкретній ситуації. I тут на допомогу прийде розмовний стиль, зокрема його різновид - розмовнопрофесійний [3, с. 117-118].

Робота викладача 3 удосконалення лексичних умінь і навичок студентів повинна збагатити їхній словниковий запас та розвинути навички самоконтролю власного мовлення, про що свідчитиме відсутність у ньому лексичних помилок. Як зазначають науковці, лексична помилка - це порушення лексичних норм (уживання слова у невластивому йому значенні; невдалий добір синонімів; сплутування різних за значенням, але близьких за звуковим оформленням слів (паронімів); лексичні анахронізми; порушення лексичної сполучуваності слів; повторення спільнокореневих слів (тавтологія); сплутування українських і російських слів; 
калькування російських слів і словосполучень (дослівний переклад їх українською мовою); неправильне вживання міжмовних омонімів) [2, с. 184].

Робота з усунення лексичних помилок повинна грунтуватися на системі вправ. Розглянемо, які тренувальні вправи доцільно використати у процесі вивчення різних груп слів за лексичним значенням (синонімів, паронімів, омонімів).

Робота з синонімами грунтується на особливостях цих слів, а саме: тотожності або близькості їх значення, з одного боку, та різниці (смислових відтінках, різному емоційному й стилістичному забарвленні) - 3 іншого. Тому дієвими $є$ лексичні вправи на закріплення семантики синонімів та словосполучень 3 ними.

Т. Коршун рекомендує [2, с. 178-179] поділити лексичні вправи на 2 блоки, що спрямовані на:

1) запам'ятовування семантики слова в єдності з вимовою і граматичною формою;

2) формування сполучень слів смислового характеру.

До 1 блоку належать вправи з такими завданнями: вибрати з ряду слів одне, що відповідає певній ситуації (темі); вилучити з ряду слів те, що неадекватне певній ситуації (темі); доповнити речення словами, що підходять; ужити в певному реченні синонім до виділеного слова.

Вправи 2 блоку мають чітко окреслене завдання - побудувати словосполучення, ураховуючи тематичне коло слів, що утворюють широкий мовленнєвий фон для використання синонімів.

Пропонуємо зразки вправ на удосконалення умінь i навичок студентів використовувати синоніми в професійному мовленні.

Вправа 1. Перепишіть слова, групуючи їх за синонімічними рядами.

Аналізувати, виконувати, нагородити, спростовувати, контролювати, розглядати, конкурувати, реалізувати, заперечувати, консультувати, аргументувати, преміювати, інспектувати, пропонувати, досліджувати, обгрунтовувати, удостоїти, втілювати, боротися, доводити, радити, чинити, ревізувати, змагатися, відхиляти.

Вправа 2. До виділених слів доберіть синоніми.

Тактовний чоловік - ... . Встановлювати зв'язки - ... Ірунтовні знання - ... . Дбати про колектив - ... . Детальна інформація - ... Матеріальна допомога - ... . Фахівець з комп'ютерної інженерії - ... . Завідувати відділом - .. . Запропонувати кандидатуру - ... . Координувати роботу - ... .

Вправа 3. За тлумачним словником з'ясуйте значеннєві відтінки слів одного синонімічного ряду. Кожне слово уведіть у контекст.

Допомога, дотація; колегіальний, колективний; нагода, можливість; фіктивний, вигаданий; численний, неодноразовий; небезпідставний, вмотивований; ідентифікувати, ототожнювати; дефіцит, нестача.

Bправа 4. Доберіть 3 довідки стрижневе слово (домінанту) до слів кожного синонімічного ряду.

1. Самостійність, незалежність - ... . 2. Довгоочікуваний, жаданий - ... 3. Недолік, дефект - .. . 4. Модифікація, видозмінювання - .. . 5. Постанова, декрет - .. . 6. Систематизувати, упорядковувати - ... . 7. Обізнаний, кваліфікований - . . . 8. Форум, симпозіум - ... 9. Короткий, небагатослівний - ... . 10. Підтримка, допомога - ...

Довідка: вада, конференція, сприяння, бажаний, стислий, класифікувати, указ, компетентний, варіювання, автономія.

Вправа 5. Випишіть зі словника синонімів 5-6 рядів слів за профілем обраної спеціальності. 
Приклад: юридичний, правничий, правовий, правознавчий.

Вправа 6. Виберіть із дужок потрібне слово. Обгрунтуйте свій вибір.

Науковий (робітник, працівник), (об’єм, обсяг) інформації, (ящик, шухляда) письмового стола, (вагання, коливання) у виборі професії, (одержати, здобути) перемогу, на лекції було розглянуто такі (питання, запитання), (вислухати, заслухати) співрозмовника, (становище, стан) хворого, (спинюся, зупинюся) на цьому питанні.

Ці вправи дозволяють акцентувати увагу студентів на семантичних відтінках близьких за значенням слів, їх сполучуваності з іншими словами та функціонуванні синонімів у визначених контекстуальних умовах.

Неабиякі труднощі у студентів викликають пароніми. У шкільному курсі української мови ця група лексики детально не вивчалась, тому проблема розрізнення паронімів та їх уживання у фаховому мовленні потребує посиленої уваги викладача на практичних заняттях. Складність засвоєння паронімів пов'язана 3 їх звуковою та структурною подібністю, що призводить до виникнення лексичних помилок. Запобігти сплутуванню таких слів можна за допомогою низки вправ, спрямованих на 3'ясування семантики паронімів, вибору пароніма з урахуванням контекстуального оточення, редагування конструкцій, як-от:

Завдання 1. Поясніть лексичне значення слів-паронімів. Кожен член паронімічної пари уведіть у речення.

Економія - економіка, освітлений - освічений, абонент - абонемент, гарячий горючий, відповідно - відповідально, ефектно - ефективно, пам'ятка - пам'ятник, засвоювати - освоювати, виплата - оплата, гарантійний - гарантований, перекладацький - перекладний, хронічний - хронологічний.

Завдання 2. Із довідки доберіть слова-пароніми до поданих визначень.

1. Той, хто посилає лист, телеграму, відправник. - Той, кому адресується лист, телеграма, одержувач.

2. Дати відомості, інформацію. - Представити, рекомендувати.

3. Бути причиною чогось, створювати передумови. - Визначати умови, обмежувати певною умовою.

4. Марне витрачення чогось, збитки. - Гроші, матеріальні цінності, енергія, сила, праця, затрачені на що-небудь.

5. Адміністративно-самостійний об'єкт або виробничий вузол на будівництві, підприємстві тощо. - Частина якої-небудь поверхні, земельної площі; галузь, сфера діяльності.

6. Сукупність людей, що становлять подібну з певного погляду групу; склад осіб певної категорії. - Материк, велика ділянка суші, оточена з усіх боків океаном.

7. Виконувати щось точно, забезпечувати наявність чогось. - Бути прихильником якоїсь думки, поглядів, переконань; керуватися ними у своїх діях.

8. Закладений, розпочатий будівництвом, створений. - Який грунтується на чомусь.

9. Особа, відзначена почесним дипломом за видатні успіхи в якій-небудь галузі. - Службова особа, яка займається дипломатичною діяльністю.

10. Група осіб, об'єднана певними інтересами, товариство. - Сукупність заходів для здійснення важливих громадсько-політичних, господарських або культурних завдань.

Довідка: дільниця - ділянка, компанія - кампанія, дипломант - дипломат, контингент - континент, зумовлювати - обумовлювати, втрати - затрати, 
заснований - оснований, ознайомити - познайомити, адресант - адресат, додержувати - додержуватися.

Завдання 3. Перепишіть речення, вибравши з дужок правильний варіант слова.

Валентина Павлівна - (тактовна, тактична) людина. У читальному залі ми користуємося алфавітним (покажчиком, показником). Протягом тижня він (вникав, уникав) у суть справи. Сергій Костюченко був (здатний, здібний) до вивчення іноземних мов. У деканаті зберігаються (особисті, особові) справи студентів. Молодому спеціалістові його наставник надав (методологічну, методичну) допомогу. Лекція мала (інформаційний, інформативний) характер. Петро Петрович (ознайомив, познайомив) мене зі своїми друзями.

Завдання 4. Узгодьте подані нижче прикметники-пароніми з іменниками, що в дужках.

1. Виборний / виборчий (агітація, кампанія, посада, бюлетень).

2. Первинний / первісний (суспільство, обробка, організація, ознака, епоха).

3. Гарантійний / гарантований (талон, заробіток, договір, право, паспорт).

4. Військовий / воєнний (період, квиток, маневр, звання, стратегія).

5. Письменний / письмовий (розпорядження, людина, екзамен).

6. Численний / числовий (функція, знак, факти, праці, послідовність).

Завдання 5. Виправте помилки, допущені внаслідок сплутування паронімів.

Задля вчасного виконання плану ми окреслили коло задач. Іванові Васильовичу Морозу було присуджено науковий степінь кандидата технічних наук. Цей студент виключно талановитий. Із продажу було вилучено дефективний товар. На адрес нашої установи надійшов службовий лист. Інженер Онищенко Степан Іванович має високий професіональний рівень. Громадський обов'язок кожного узяти участь у виборах. Він не має жодної уяви про специфіку цього механізму. Вартість комп'ютера становить 5000 гривен.

Такі вправи формують і вдосконалюють уміння й навички студентів точно формулювати думку, ураховуючи лексичну сполучуваність паронімів та способи їх граматичного зв'язку з іншими словами.

3-поміж фахових термінів виділяють ті, що виступають омонімами до загальновживаних слів. Явище омонімії - наслідок випадкового збігу звучання, у значенні ж слова-омоніми не мають абсолютно нічого спільного. При вивченні цієї групи лексики слід наголосити на джерелах омонімії, а саме: 1) випадковий збіг неспоріднених слів: термін (слово) - термін (строк); 2) розпад багатозначного слова: переказати (переповісти) - переказати (гроші); 3) словотворчі процеси: винний (вина) - винний (вино); 4) збіг абревіатури та вже наявного в мові слова: CTO (станція технічного обслуговування) - cmo (100); 5) збіг українського та іншомовного слова: клуб (диму) - клуб (з англ. - товариство, приміщення); 6) засвоєння з різних мов: ліга (з франц. - асоціація) - ліга (з італ. - знак над нотами у вигляді дуги) [1, с. 149-150]. Задля кращого засвоєння семантики слів-омонімів пропонуємо такі завдання:

Завдання 1. Ознайомтеся з лексичним значенням слів, поданих у «Словнику омонімів української мови» за редакцією О. Демської та І. Кульчицького (Львів, 1996). Уведіть кожне слово в окреме речення.

1. Акція I. Цінний папір. Акція II. Дія, вчинена 3 якоюсь політичною, економічною метою тощо.

2. Бак I. Велика закрита посудина для рідини. Бак II. Носова частина верхньої палуби судна. 
3. Балка I. Яр з пологими схилами. Балка II. Колода або брус в основі перекриття, настилу (стелі, підлоги).

4. Блок I. Механізм для підняття вантажів, важких предметів.

Блок II. Окрема незалежна частина споруди, машини.

Блок III. Об'єднання держав, партій і т. ін.

5. Бурка I. Плащ або накидка з козячої вовни. Бурка II. Спеціальний отвір у гірських спорудах, який наповнюють вибуховою речовиною, аби висадити їх у повітря.

6. Вибій I. Заглибина, отвір, що виникли внаслідок ударяння, частої їзди. Вибій II. Кінець гірничого виробітку; місце роботи шахтаря.

7. Відпалювати I. Обробляти метали тощо нагріванням та повільним охолодженням. Відпалювати II. Робити отвір, щілину в пласті вугілля, руди за допомогою вибуху.

8. Гіпербола I. Стилістичний засіб навмисного перебільшення. Гіпербола II. Геометрична незамкнена крива 3 двох гілок.

9. Емісія I. Випуск банкнотів, паперових грошей та цінних паперів. Eмісія II. Випромінення електронів, іонів твердими або рідкими тілами.

10. Завод I. Велике промислове підприємство. Завод II. Сільськогосподарське підприємство, де розводять породистих домашніх тварин. Завод III. 1. Пристрій для заведення механізмів.2. Гранична тривалість дії заведеного механізму.

Завдання 2. Доберіть 5 фахових термінів, що $є$ омонімами до інших слів. Поясніть значення всіх слів самостійно, а потім перевірте себе за тлумачним словником.

У професійному спілкуванні часто трапляються лексичні помилки, спричинені нерозрізненням міжмовних омонімів - однакових або близьких за звучанням слів, що позначають різні поняття в споріднених мовах. Тому на практичних заняттях 3 курсу «Українська мова (за професійним спрямуванням)» доцільно використати роботу зі «Словником російсько-українських міжмовних омонімів» за редакцією М. Кочергана (К., 1997).

Завдання 3. Зіставте лексичне значення міжмовних омонімів у двох споріднених мовах. Поясніть, чому ці слова називають «фальшивими друзями перекладача», «ключами, що відмикають зовсім різну дійсність».

\begin{tabular}{|l|l|}
\hline Російська мова & Українська мова \\
\hline брак & брак \\
\hline витать & вітати \\
\hline властный & власний \\
\hline глупый & глупий \\
\hline довольный & довільний \\
\hline заборонить & заборонити \\
\hline корыстный & корисний \\
\hline листопад & листопад \\
\hline лишить & лишити \\
\hline пыльный & пильний \\
\hline пытать & питати \\
\hline
\end{tabular}

Удосконалити лексичні вміння та навички студентів допоможуть вправи на редагування конструкцій з міжмовними омонімами, як-от: 
Завдання 4. Виправити помилки, пов'язані з явищем міжмовної інтерференції.

1. Зимові канікули тривали одну неділю. 2. На контрольній роботі необхідно було доказати теорему. 3. Ї̈̈ заставляли працювати без вихідних. 4. За жорстоке ставлення до власних дітей Василя Петренка суд лишив батьківських прав. 5. Наглий юнак образив літню жінку. 6. Студент не встиг розв'язати задачу, оскільки йому постійно мішали одногрупники. 7. На спортивних змаганнях ми боліли за команду нашого університету. 8. На екзамені Олег одержав низьку оцінку, тому що спутав формули.

Отже, застосування в навчальному процесі окресленої системи вправ сприяє грунтовному засвоєнню базових лексичних понять та вдосконаленню комунікативних умінь i навичок користуватися словом у сфері професійного спілкування.

\section{Література}

1. Мацюк 3. О. Українська мова професійного спілкування : навч. посіб./ 3. О. Мацюк, Н. І. Станкевич. - К. : Каравела, 2005. - 352 с. 2. Методика навчання української мови в середніх освітніх закладах / [Пентилюк М. І., Караман С. О., Караман О. В. та ін.] ; за ред. М. І. Пентилюк. - К. : Ленвіт, 2005. - 400 с. 3. Шевчук С. В. Українська мова за професійним спрямуванням : підручник / С. В. Шевчук, І. В. Клименко. - К. : Алерта, 2013. - 696 с.

УДК 378.147

Леся Потапкіна

\section{ШЛЯХИ РОЗВИТКУ В МАЙБУТНІХ ЕКОНОМІСТІВ УПРАВЛІНСЬКИХ ЯКОСТЕЙ І НАВИЧОК РОБОТИ В КОМАНДІ}

Потапкіна Л. В. Шляхи розвитку в майбутніх економістів управлінських якостей і навичок роботи в команді.

У статті виокремлено найважливіші здібності та якості, якими повинні володіти сучасні фахівці з менеджменту, визначено зачади досягнень менеджерів, економістів, подано методичні настанови, необхідні для ділової активності вдосконалення професійних здібностей, надано поради задля досягнення успіху на початковому етапі, наведено приклади використання в навчальному процесі ділових, імітаційних, інтелектуальних ігор та тренінгів, здійснили оцінку компетенцій.

Ключові слова: досягнення, ділова активність, професійні здібності, компетентність, тренінг.

Потапкина Л. В. Пути развития у будущих экономистов управленческих качеств и навыков работы в команде.

В статье выделены важнейшие способности и качества, которыми должны владеть современные специалисты по менеджменту, определены основы достижений менеджеров, экономистов, представлены методические установки, необходимые для деловой активности совершенствования профессиональных способностей, предоставлено советы для достижения успеха, приведены примеры использования в учебном процессе деловых, имитационных, интеллектуальных игр и тренингов, осуществили оценку компетенций.

Ключевые слова: достижение, деловая активность, профессиональные способности, компетентность, тренинг. 